\title{
Methodical Aspects of Sustainable Development Assessment of Krasnoyarsk Region
}

\author{
Irina Sergeevna Ferova \\ Siberian federal university \\ iferova@sfu-kras.ru \\ Elena Valerevna Lobkova \\ Siberian federal university
}

\author{
Ekaterina Nikolaevna Tanenkova \\ Siberian federal university \\ Svetlana Aleksandrovna Kozlova
Siberian federal university
}

\begin{abstract}
The problems of sustainable development are becoming currently more and more important. In this context, the determining factor for making effective management decisions by governing institutions depends on the choice of assessment methods, particular indicators for analyzing stability conditions, as well as ways of collecting trustworthy information and data-processing procedures.

This paper is aimed at analyzing available approaches and tools for monitoring regional development, building internal methodological and methodic basis for assessment the sustainability of regions in order to solve socio-economic problems. Not only that, but consideration of institutional development of territories and the effects of trans-regional interaction and inter-disciplinarity should become the main conceptual and methodological prerequisite emblematic of the proposed approach. There is no consensus among modern scholars on the theoretical aspects of the assessment of sustainable development, as well as on the use of the information base, and on methodological issues of the monitoring procedure, especially in the context of the cluster approach.

The paper analyses current methods for assessing the sustainable development of systems at various levels - national and regional economies, territories, industries, enterprises, products. The determinants of institutional development at the regional level have been analyzed. For assessing and forecasting sustainable development, the authors suggest using a modified TOPSIS method that takes into account the multiplicative effects of implementing a cluster development model. At the same time, the main problem of using methods for assessing socio-economic and sustainable development, as well as institutional environment and its changes is the limitation of the available data. Use of digital technologies and big data is regarded as a solution to this problem.
\end{abstract}

Keywords: monitoring, sustainable development, cluster model, institutional changes, method TOPSIS, digital economy, big data, Krasnoyarsk region

\section{INTRODUCTION}

The traditional approach to the choice for the tools to assess sustainability is formation of a list of indicators (both statistical and expert ones), converting them to the type required for assessing and calculating an aggregate sustainability index $[1,2]$. The field of broad scientific discussions and searches is to determine the most appropriate methods (ways) to implement the concept of sustainable development in the economic reality, to identify the right goals and relevant indicators of their achievement, to translate the concept of durability into categories of measurable phenomena, the scope of research on the implementation of sustainable development in individual economies, and methods and measures that should be used for this assessment and commonly used in temporary and cross-sectional comparative analyzes [3].

The results of this procedure are used to develop recommendations to the administrative bodies of a facility (territory) and to conduct a comparative assessment of the development and sustainability level of different countries, regions, cities, etc. [4, 5] There are three aspects of sustainability: economic, social and environmental. Each of them may include additional assessment areas or aspects at the author' discretion.

Today the investigation of the problems of sustainable development of territory is carried out by S.N. Bobilev, B.N. Porfiriev [6].

In 2011 there was suggested the project "Mechanisms of sustainable development for big cities and their global net (using the example of Moscow)" under the program "Monitoring and governing of global processes in big cities" and under activity of Moscow department UNESCO MGU for global issues.

The Technique for order preference by similarity to ideal solution (TOPSIS) developed by Hwang \& Yoon [7] in 1981 
explain how structural changes in regional industrial complexes influence socio- economic development and its sustainability (considering the development of new economic relations in Yenisei economic area).

The methodology of monitoring and assessing socioeconomic development gives an opportunity to determine an effective direction of industrial policy. Multiplicative effects of the described processes can be positive dynamics in socio economic indicators of Krasnoyarsk region, growth in indicators which reflect stability of regional budgets, stimulation of investments, positive changes in population's quality of life.

On the first stage of the project authors suggest studying the following tasks:

1. Analysis of the socio- economic development of three regions, which are included in Yenisei Siberia;

2. Identification of potential points of growth;

3. Analysis of an institutional background from the creation of Yenisei economic area and development of regional industrial policy, based on cluster approach, considering interrelation between regions;

4. Estimation of the impact of enterprises and industrial sectors, analysis of functioning of the largest enterprises and industries in the Krasnoyarsk region and other Siberian regions, assessment of interrelations between industries and regions.

5. Development of a monitoring program and methodology of assessment of the regional stainable development (with emphasis on the specific development of small towns and non- urbanized rural areas), taking into account the impact of industrial enterprises on the socio- economic development, integrational processes of Yenisei economic area and implementation of advantages of cluster approach in making industrial policy as well;

6. To create the directions of efficient industrial policy, which would be devoted to the stimulation of socioeconomic indicators of economic development and quality of population's life.

\section{RESULTS}

Generally, mechanisms of regional economic policy can be determined as directed measures regarding sustainable growth of production in different sectors of economy, as well as overcoming problems of competitive advantages, variety of products, etc. In this case the identification of the main policy makers and other agents and groups, who can influence the direction of the policy, is very important. As a rule, it is distinguished three levels of regulation: federal; regional and local. In table 1 we tried to illustrate the participation of different levels of government regulation in regional development.

Table 1 demonstrates that the main role in making policy decisions plays regional level of government regulation. It means that implementation of policy measures and events,

characteristics of these processes, based on the model, which 
TABLE I

DIFFERENT LEVELS OF GOVERNMENT PARTICIPATION IN REGIONAL ECONOMIC PROBLEMS

\begin{tabular}{|l|l|l|l|}
\hline \multicolumn{2}{|c|}{ Regional problems (are regulated by government decisions) } & \multicolumn{2}{c|}{ Levels } \\
\cline { 2 - 4 } & fegional & local \\
\hline Development of resources of pioneer or extreme areas & $\mathrm{B}$ & - & - \\
\hline Rationalization of the regional economy & $\mathrm{A}$ & $\mathrm{B}$ & $\mathrm{A}$ \\
\hline Using of natural resources in region & - & $\mathrm{B}$ & $\mathrm{A}$ \\
\hline Provision of regional infrastructure & - & $\mathrm{B}$ & $\mathrm{A}$ \\
\hline Supporting of appropriate level of unemployment & $\mathrm{B}$ & $\mathrm{B}$ & $\mathrm{A}$ \\
\hline Provision of an appropriate level of public services & $\mathrm{A}$ & $\mathrm{B}$ & $\mathrm{B}$ \\
\hline Servicing of ecological programs & $\mathrm{B}$ & $\mathrm{B}$ & $\mathrm{A}$ \\
\hline Smoothing regional differentiation & $\mathrm{B}$ & $\mathrm{B}$ & - \\
\hline Provision of rational connections & $\mathrm{B}$ & $\mathrm{B}$ & - \\
\hline Creation of special areas & $\mathrm{B}$ & $\mathrm{B}$ \\
\hline & \multicolumn{3}{|l}{${ }^{\mathrm{a} .}$ Designation of gradation levels: B - basic; A - additional } \\
\hline
\end{tabular}

according to the cluster model, should be realized on the regional level.

From our point of view the development of regional policy should include two aspects. The first one is a necessity of classification of policy events regarding to the specific of cluster. The second one includes the process and mechanism of cluster creation. Here we can highlight the following points: stimulating measures for cluster development (for young clusters as well as for new cluster schemes); supporting measures for existing clusters and measures for monitoring (namely assessment of the impact and adjustment). Moreover, these measures can be implemented into two levels: into administrative level and into the level of enterprises. In the first case the subject of cluster policy should be regional government, who creates the conditions for building industrial interrelations and creation of cluster schemes. It is natural here to consider social effect, reflecting in increasing number of workplaces, quality of life etc. From the perspective of firm and enterprises the efficiency of cluster policy is expressed in reducing costs and gaining the economy of scale.

During the study of institutional changes in terms of its efficiency and quality, we faced with some theoretical problems concerning the absence of general approach of institutional estimation and assessment. Usually in scientific literature the efficiency and effectiveness of institutions and its changes is estimated by macroeconomic indicators, proxy and criteria, which cannot reflect the actual situation. Researchers [20 - 26] argued that such an approach has following disadvantages:

- Lack of general approach in institutional parameters/ characteristics which should be measured and placed in the model as well as some parameters can be missed. Effective institutions provide security of property rights, reduce risks of expropriation, support system of courts, political efficiency etc. The multi - aspect of institutions become a problem for the research as it demands to include in the model all factors. That is why in general model the factors are aggregated and some of them is neglected. It makes impossible to study all positive and negative institutional effects.

- The problem of results' interpretation. Most of the studies provide wide and general results which are difficult to interpret. Here the problem of exogeneity/ endogeneity exists as well.

- The measurement of institutions is often based on the "perception" and expert judgment of foreign agents. On the one hand, for developed countries such result can be percept as a motivation for the further development of their institutions. On the other hand, for developing countries, "perception" characterizes only the quality of formal institutions. Obviously, the quality of formal institutions of developing countries from the point of view of foreign experts can be defined as low. The question of assessing the quality of informal institutions using this approach remains open.

From the perspective of economic analysis of mesoinstitutional level, which obtain effective economic growth, it seems to be reasonable to discuss the investment project of "Yenisei Siberia". The main aim of this project is a socio- economic development of three regions: Krasnoyarsk region, Khakassia Republic and Tyva Republic. The project includes the development of different economic sectors such as energy, mining and processing of minerals, agriculture, transport and infrastructure. It is supposed that the main economic agents in this project will be regional government, firms and organizations, educational and scientific organizations. The investment mechanisms, mechanisms of creation new workplaces, mobility and supporting measures for SME's here can be realized through public -private partnership and creation of interregional clusters. As it is expected, the project of "Yenisei Siberia" will obtain three regions with institutional and social basis through efficient conditions for cooperation, supporting and developing SME's and increasing competitiveness of each region.

As our analysis shows Krasnoyarsk region possesses the higher level of social capital compared with Tyva and Khakassia. Most of the researchers find out that the level of institutional development is directly influenced by the level of social capital. For instance, in Siberian federal district the level of social capital can be estimated as rather high. Table 2 demonstrates the place of the region according to the level of trust.

The innovation activity in Krasnoyarsk region can be estimated as rather high. Potentially in region there are some 
TABLE II.

REGINAL RANKING OF TRUST [22]

\begin{tabular}{|l|c|c|c|}
\hline \multicolumn{1}{|c|}{ Regions } & $\begin{array}{c}\text { Most people are honest, they can } \\
\text { be trusted (\%) }\end{array}$ & Everybody lies, be careful (\%) & Other answer (\%) \\
\hline \multicolumn{4}{|c|}{ Regions with high level of trust } \\
\hline Ural federal district & 49.5 & 46.8 & 3.7 \\
\hline Central federal district & 34.3 & 60.2 & 5.4 \\
\hline \multicolumn{4}{|l|}{ Regions with middle level of trust } \\
\hline Siberian federal district & 26.6 & 68.1 & 5.3 \\
\hline South federal district & 24.4 & 72.1 & 3.5 \\
\hline Volga federal district & 23.3 & 74.3 & 2.3 \\
\hline \multicolumn{2}{|c|}{ Regions with low level of trust } \\
\hline Northwestern federal district & 21.6 & 62.7 & 15.7 \\
\hline Far Eastern federal district & 15.9 & 80.7 & 3.4 \\
\hline
\end{tabular}

firms and organizations with $\mathrm{R} \& \mathrm{D}$, but at the same time in all three regions the number of innovation firms and organizations from 2010 to 2017 has reduced.

In result the level of social capital in Krasnoyarsk is higher than in other regions, that is why from our opinion, the institutional environment in Krasnoyarsk is more effective.

"Yenisei Siberia" project covers three regions, so it is necessary to create effective institutions for implementing mechanisms of private public partnership and clusters. The government here plays an important role in making rules of game and ensuring its implementation.

Today the main problem of assessment is lack of available data. Using big data can solve this problem. Big data is not systematized data about socio- economic development and environment, generated based on information and communication technologies outside the official statistics. The characteristics of big data are as follows: great amount of information, high speed of change information, diversity and heterogeneity of data. For official statistic the strategic value of big data can be characterized by [27]:

- More detailed and specified information;

- Frequency of estimation;

- New possibilities in gaining and processing information;

- The increase of reliability of data and estimations.

The main problems of using big data in statistics are ensuring confidentiality, financing and appropriate and well qualified specialists in this sphere.

\section{DISCUSSION}

The structured problems of using big data are as follows [28 - 31]:

- Legal problems, concerning with access for private sector, government organizations and others;

- Problems related with confidentiality of personal data. Here it is necessary to obtain guarantees of public confidentiality, public trust and rules of using data;

- Financial problems connected with reducing costs of access;
- Management problems: changing in management, ensuring and protection;

- Methodological problems: new approaches in gaining, systematization, processing and estimation;

- Technological problems: creation information technologies for transfer and data storage.

- Staffing problems: new skills and knowledges in the field of methodology, analysis and processing.

\section{CONCLUSION}

The study was financially supported by the Russian Foundation for Basic Research, the Government of the Krasnoyarsk krai, the Krasnoyarsk krai Science Foundation as part of the scientific project No. 18-410-242005 r_mk "Development of a methodology for assessing the sustainable development of the territories of the Krasnoyarsk region".

\section{References}

[1] T. Lützkendorf and M. Balouktsi, "Assessing a Sustainable Urban Development: Typology of Indicators and Sources of Information", Procedia Environmental Sciences, vol. 38, pp. 546-553, 2017.

[2] Ch. Wang, L. Wang, and Sh. Dai, “An indicator approach to industrial sustainability assessment: The case of China's Capital Economic Circle", Journal of Cleaner Production, vol. 194, pp. 473-482, September 2018.

[3] P. Mateusz, M. Danuta, Ł. Małgorzataa, B. Mariusz, and N. Kesra "TOPSIS and VIKOR methods in study of sustainable development in the EU countries", Procedia Computer Science, vol. 126, pp. 1683 1692, 2018.

[4] S. Salaa, B. Ciuffob, and P. Nijkampcd, "A systemic framework for sustainability assessment”, Ecological Economics, vol. 119, pp. 314325, November 2015.

[5] T.O. Olawumi and D.W.M. Chan, "A scientometric review of global research on sustainability and sustainable development", Journal of Cleaner Production, vol. 183, pp. 231-250, 10 May 2018.

[6] B.N.Porfi r'ev and S.N. Bobylev, "Ustoychivoe razvitie krupneyshikh gorodov i megapolisov: faktor ekosistemnykh uslug”, Vestn. Mosk. unta., Ekonomika, ser. 6, no. 6, 2016.

[7] C.L. Hwang and K. Yoon, "Multiple Attribute Decision Making: Methods and Applications a State-of-the-Art Survey", Springer Science \& Business Media: Medford, MA, USA, vol. 186, 2012.

[8] Y. Li, L. Zhao, and J. Suo, "Comprehensive assessment on sustainable development of highway transportation capacity based on entropy weight and TOPSIS", Sustainability, 6, pp. 4685-4693, 2014. 
[20] J. Jütting and et al., Institutions and development: a critical review. OECD Publishing, t. 11, p.18 (47 p.), 2004.

[9] J. Huang, "Combining entropy weight and TOPSIS method for information system selection", In Proceedings of the 2008 IEEE Conference on Cybernetics and Intelligent Systems, Chengdu, China, pp. 1965-1968, 21-24 September 2008.

[10] Y.M. Wang and T.M. Elhag, "TOPSIS method based on alpha level sets with an application to bridge risk assessment”, Expert Syst. Appl., 31, pp. 309-319, 2006.

[11] G. Torlak, M. Sevkli, M. Sanal, and S. Zaim, "Analyzing business competition by using fuzzy TOPSIS method: An example of Turkish domestic airline industry", Expert Syst. Appl., 38, pp. 3396-3406, 2011.

[12] C.C. Sun and G.T. Lin, "Using fuzzy TOPSIS method for evaluating the competitive advantages of shopping websites", Expert Syst. Appl., 36, pp. 11764-11771, 2009.

[13] L. Anselin, "Local indicators of spatial association", LISA. Geogr. Anal., 27, pp. 3-115, 1995.

[14] X. Zhang, X. Ao, W. Caic, Zh. Jiang, and H., Zhang, "A sustainability evaluation method integrating the energy, economic and environment in remanufacturing systems", Journal of Cleaner Production, vol. 239, 118100, 1 December 2019.

[15] Sh. Zhou, W. Liu, and W. Chang, "An improved TOPSIS with weighted hesitant vague information”, Chaos, Solitons \& Fractals, vol. 89, pp. 47-53, August 2016.

[16] R. Lourenzutti and R. Krohling, "A generalized TOPSIS method for group decision making with heterogeneous information in a dynamic environment", Information Sciences, vol. 330, pp. 1-18, 10 February 2016.

[17] R.F. de Farias Aires and L. Ferreira, "A new approach to avoid rank reversal cases in the TOPSIS method", Computers \& Industrial Engineering, vol. 132, pp. 84-97, June 2019.

[18] B. Dutta, T. Singha, M. Goh, M.T. Lamata, and J.L. Verdegay, "Post factum analysis in TOPSIS based decision making method", Expert Systems with Applications, vol. 138, December 2019.

[19] D. Kacprzak, "A doubly extended TOPSIS method for group decision making based on ordered fuzzy numbers", Expert Systems with Applications, vol. 116, pp. 243-254, February 2019.

[21] M. Sasaki, V. Davydenko, Yu. Latov, and G. Romashkin, "Doverie kak element sotsial'nogo kapitala sovremennoy Rossii (komparativistskiy analiz)", Mir Rossii, Sotsiologiya, Etnologiya, no. 2, 2010.

[22] "Bol'shie dannye dlya gosudarstvennogo upravleniya: prezentatsiya", Analiticheskogo tsentra pri Pravitel'stve RF, Moskva, Analiticheskiy tsentr pri Pravitel'stve RF, 2016 [Electronic resource]. Available at: http://ac.gov.ru/files/content/10087/pushkin-bolshie-dannye-dlyagosupravleniya-pdf.pdf.

[23] R.D. Gastil, Freedom in the World. Freedom House, 1990.

[24] S. Knack and P. Keefer, "Institutions and economic performance: cross country tests using alternative institutional measures", Economics and Politics, vol. 7, no. 3, pp. 207-227, 1995.

[25] J.A. Alonso and C. Garcimartin, "The determinants of Institutional Quality. More on the Debate", CREDIT Research Paper, no. 09/04, pp.1-28, 2009.

[26] J. Aron, "Growth and institutions: a review of the evidence", The World Bank Research Observer, t. 15, no. 1, 2000.

[27] N.S. Karpova, A.E. Surinov, I.S. Ul'yanov, "Problemy i vozmozhnosti ispol'zovaniya bol'shikh dannykh v rossiyskoy statistike", Voprosy statistiki, 7, pp. 3-9, 2016. DOI: 10.34023/2313-6383-2016-0-7-3-9.

[28] R. Dubey, A. Gunasekaran, S. Childe, Th. Papadopoulos, Z. Luo, S. Wamba, and D. Roubaud, "Can big data and predictive analytics improve social and environmental sustainability?", Technological Forecasting and Social Change, vol. 144, pp. 534-545, July 2019.

[29] A. Merendino, S. Dibb, M. Meadows, L. Quinn, D. Wilson, L. Simkin, and A. Canhoto, "Big data, big decisions: The impact of big data on board level decision-making", Journal of Business Research, vol. 93, pp. 67-78, December 2018.

[30] M. Song, L. Cen, Zh. Zheng, R. Fishe, X. Liang, Y. Wang, and D. Huisingh, "How would big data support societal development and environmental sustainability?", Insights and practices, Journal of Cleaner Production, vol. 142, part 2, pp. 489-500, 20 January 2017.

[31] R. Herschel and V. Miori, "Ethics \& Big Data", Technology in Society, vol. 49, pp. 31-36, May 2017. 